\title{
First record of Eumops perotis (Schinz, 1821) (Chiroptera, Molossidae) from the Cerrado of Mato Grosso do Sul, Central-West Brazil
}

\author{
Jaire Marinho Torres ${ }^{1}$, Grasiela Edith de Oliveira Porfirio ${ }^{2}$, Priscila Ikeda ${ }^{3}$, Marcelo Oscar \\ Bordignon $^{4}$, Filipe Martins Santos ${ }^{5}$, Carina Elisei ${ }^{1,5}$
}

\begin{abstract}
1 Programa de Pós-Graduação em Biotecnologia, Universidade Católica Dom Bosco, Campo Grande, MS, Avenida Tamandaré, 6000, CEP 79117900, Brazil. 2 Pós-graduação em Recursos Naturais, Universidade Federal de Mato Grosso do Sul, Campo Grande, MS, Cidade Universitária, s/n, CEP 79070-900, Brazil. 3 Programa de Pós-Graduação em Medicina Veterinária, Universidade Estadual Paulista Júlio de Mesquita Filho, Jaboticabal, SP, Via de Acesso Prof. Paulo Donato Castellane, s/n, CEP 14884-900, Brazil. 4 Programa de Pós-Graduação em Biologia Animal, Universidade Federal de Mato Grosso do Sul, Campo Grande, MS, Cidade Universitária, s/n, CEP 79070-900, Brazil. 5 Programa de Pós-Graduação em Ciências Ambientais e Sustentabilidade Agropecuária, Universidade Católica Dom Bosco, Campo Grande, MS, Avenida Tamandaré, 6000, CEP 79117-900, Brazil.
\end{abstract}

Corresponding author: Jaire Marinho Torres, jairemarinho@gmail.com

\begin{abstract}
The Greater Bonneted Bat, Eumops perotis (Schinz, 1821), is widely distributed in Brazil, but valid records of its occurrence in Mato Grosso do Sul, Central-West Region, are still scarce and limited to the Pantanal portion of the state. Here, we report the first record of E. perotis from the Cerrado portion of Mato Grosso do Sul, based on specimens collected in an urban forest remnant in the municipality of Campo Grande. These specimens add to the records of $E$. perotis in the Cerrado of the Central-West and fill gaps in the distribution of this species.
\end{abstract}

Keywords

Distribution, Greater Bonneted Bat, South America

Academic editor: Sergio Solari | Received 27 February 2020 | Accepted 14 May 2020 | Published 26 June 2020

Citation: Torres JM, Porfirio GEO, Ikeda P, Bordignon MO, Santos FM, Elisei C (2020) First record of Eumops perotis (Schinz, 1821) (Chiroptera, Molossidae) from the Cerrado of Mato Grosso do Sul, Central-West Brazil. Check List 16 (3): 759-764. https://doi.org/10.15560/16.3.759

\section{Introduction}

The genus Eumops Miller, 1906 has a wide distribution occurring from the southern United States to northern Argentina (Eger 2008), and it is considered the most diverse genus of the New World molossid bats (Gregorin et al. 2016). This genus currently comprises 16 species, of which 11 are recorded in Brazil (Nogueira et al. 2018): E. auripendulus (Shaw, 1800), E. bonariensis (Peters, 1874), E. chimaera Gregorin et al., 2016, E. dabbenei (Thomas, 1914), E. delticus Thomas, 1923, E. glaucinus
(Wagner, 1843), E. hansae Sanborn, 1932, E. maurus (Thomas, 1901), E. patagonicus Thomas, 1924, E. perotis (Schinz, 1821), and E. trumbulli (Thomas, 1901).

Eumops perotis is known from Colombia, Venezuela, Brazil, Ecuador, Peru, Bolivia, Chile, Paraguay, and northern Argentina (Sartore et al. 2017). The species is disjunct in two large populations, with the subspecies E. perotis californicus (Merriam, 1890) occurring in the southwestern United States and in northern Mexico, 
and subspecies E. p. perotis occurring in South America (Eger 2008; Sartore et al. 2017). In Brazil, the species is widely distributed, with records in 14 states, the Federal District, and in all the biomes (Feijó et al. 2010; Suckow et al. 2010; Fischer et al. 2015; Nunes et al. 2017).

The Central-West Region, however, has some of the larger gaps in the knowledge of the distribution of $E$. perotis (Fig. 1), with scarce records from the Cerrado of Federal District (Pacheco et al. 2010) and Goiás (Nunes et al. 2017), and the Pantanal of Mato Grosso (Escarlate-Tavares and Pêssoa 2005) and Mato Grosso do Sul (Fischer et al. 2015). Here, we present the first record of E. perotis for the Cerrado portion of Mato Grosso do Sul, Central-West Brazil, based on specimens collected in an urban area of the Campo Grande municipality.

\section{Methods}

The specimens were collected during an inventory around the Florestinha Environmental Education Center (FEEC; 20²4'10.90"S, 054³3'42.45"W), Campo Grande, Mato Grosso do Sul. This locality is within an urban area, near housing complexes and is a remnant of vegetation that includes portions of riparian forest, dry grassland, and savanna swamp. Captures of the specimens were conducted in December 2017, using a mist net of $12.0 \times 2.5 \mathrm{~m}$ positioned at ground level in the exit of a building.

One external and 10 cranial measurements were taken to four adults individuals with a digital caliper (accurate to $0.01 \mathrm{~mm}$ ) according to the parameters presented by Gregorin and Taddei (2002) and Reis et al. (2017): forearm length (FA), greatest length of skull (GLS), condyleincisive length (CIL), palatal length (PAL), zygomatic breadth (ZIB), post-orbital breadth (POB), braincase breadth (BCB), length of upper canine-last molar (C-M), upper molar breadth (M-M), mandible length (MAL), and length of lower canine-last molar (c-m). The taxonomic identification of the collected specimens was based on analysis of the morphological traits and measurements available for the Eumops species that occur in Brazil (Anderson 1972; Eger 1977; Best et al. 1996; Gregorin et al. 2016; Sartore et al. 2017).

Furthermore, we conducted a principal component analysis (PCA) with all external and cranial measurements variables from Eumops spp. The PCA has the

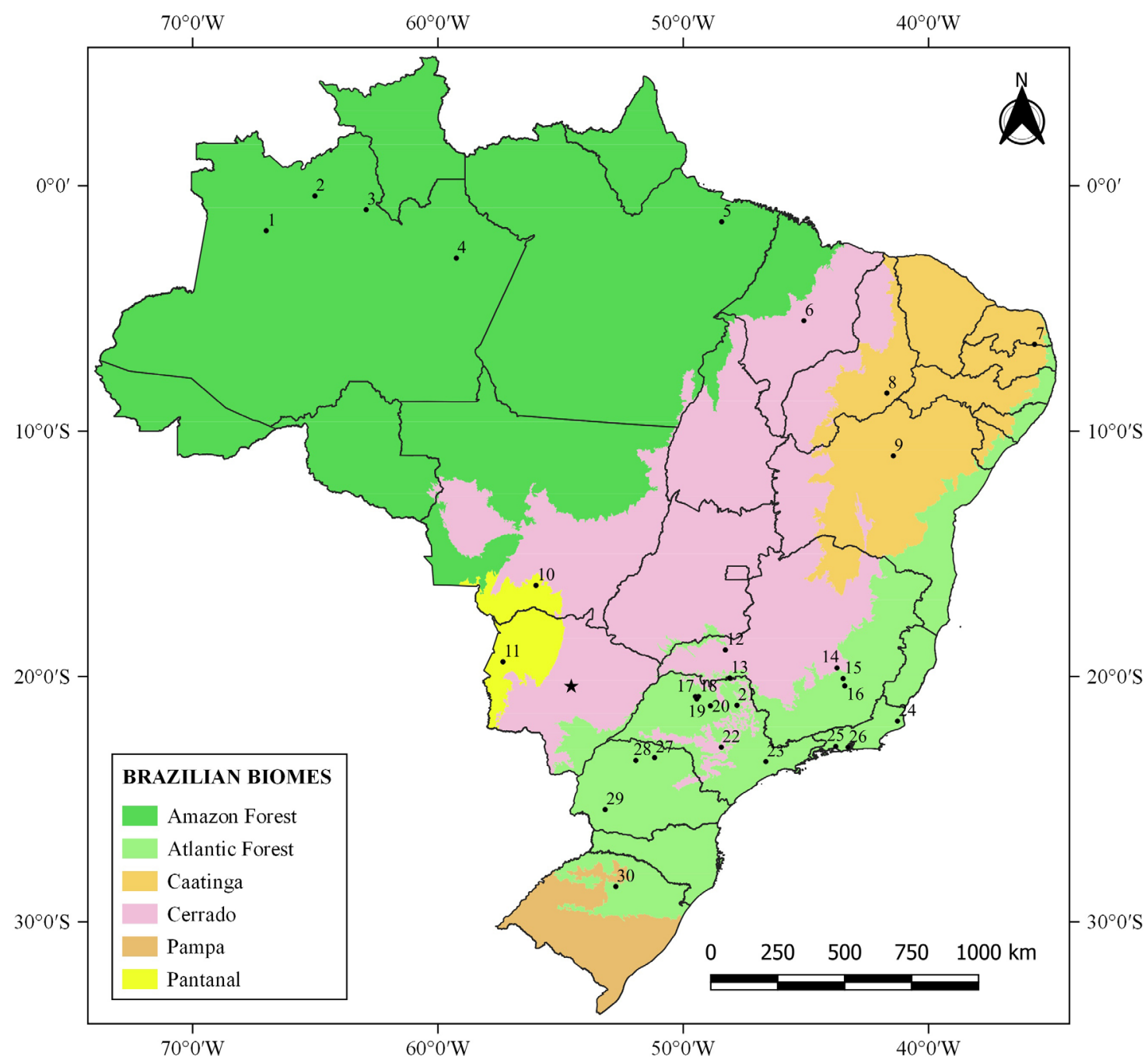

Figure 1. Distribution of Eumops perotis in Brazil. Black star: new record from Campo Grande, in the Cerrado of Mato Grosso do Sul, Central-West Brazil. Black circles: previous records. The numbers corresponding to the records are indicated in Appendix Table A1. 
objective of reducing the original data, facilitating their interpretation (Johnson and Wichern 1992). The components that accounted for most of the total variance were analyzed. A scatterplot of the best two component scores of the measurements was created to visualize the differences between $E$. perotis and other species of the genus. PCA test was computed with Past v. 3.2 (Hammer et al. 2001).

The specimens were deposited in the Zoological Reference Collection of the Federal University of Mato Grosso do Sul (ZUFMS). Fieldwork was authorized by the Brazilian Institute of Environment (ICMBio license number 56804-1) and by the Committee of Ethics for the Use of Animals of the Dom Bosco Catholic University (certification number 006/2017).

\section{Results}

New record. BRAZIL 2 ๙ 2 , 2 ; Mato Grosso do Sul, Campo Grande, Florestinha Environmental Education Center; 20²4'10.90"S, 054³3'42.45"W; 5 Dec. 2017; Jaire Marinho Torres and Priscila Ikeda leg.; ZUFMSCHI 02496-02499.

Identification. Compared to the measurements available for Eumops perotis, our specimens showed FA, CIL, $\mathrm{BCB}, \mathrm{CM}$, and MAL similar to that described for the species in other biomes of Brazil (Feijó et al. 2010; Suckow et al. 2010; Gregorin et al. 2016; Table 1). The morphological traits of our specimens fit to that of E. perotis descriptions (Anderson 1972; Eger 1977; Best et al. 1996; Bernardi et al. 2009; Gregorin et al. 2016; López-Baucells et al. 2017; Sartore et al. 2017). The specimens have a large, broad, and square tragus, and a broad and semicircular antitragus. The skull is long and flattened, with a reduced sagittal crest, and an elongated and deep basisphenoid pits. In all the specimens, the upper incisors are fused at the base, and the third upper molar has the third commissure onequarter the size of the second. A collected specimen and its skull are shown in Figure 2.

In the PCA the first two components explained, respectively, $89.4 \%$, and $9.2 \%$ of external and cranial measurements variation, $98.6 \%$ of the total variation. In addition, the measurements of $E$. perotis individuals were well separated from the other species in the scatterplot (Fig. 3).

\section{Discussion}

Eumops perotis is the largest species of the genus and resembles mainly E. trumbulli, being differentiated by the size and length of the third commissure of the third molar (Sartore et al. 2017). Additionally, E. trumbulli is endemic to the Amazon basin (Sartore et al. 2017) and it is not recorded from the state of Mato Grosso do Sul (Fischer et al. 2015).

Although E. perotis is typically sheltered in rocky cliffs (Best et al. 1996), previous studies showed that individuals of this species are commonly found in urban areas sheltering in house linings (Barquez and Díaz 2001), as we observed here. Eumops perotis has been found in urban and peri-urban areas of at least five states (Amazonas, Goiás, Minas Gerais, Paraná, São Paulo) and the Federal District (Pacheco et al. 2010; Nunes et al. 2017).

Information on the distribution of E. perotis in Brazil has improved mainly due to records of the species since the 2000s. However, records of E. perotis are still scarce, especially in the Cerrado biome, which is the second largest biome in the Brazil (Fig. 1). The first records of E. perotis in the Cerrado were obtained from the states of Maranhão and Minas Gerais in the 1970s (Eger 1977), with additional records only in 2000s, from

Table 1. Measurements of Eumops perotis specimens from Campo Grande, in the Cerrado of Mato Grosso do Sul, Central-West Brazil (present study) and from previous localities. The minimum and maximum values for the measurements are shown in millimeters. Abbreviations: $B C B$, braincase breadth; $C-M$, length of upper canine-last molar; $c-m$, length of lower canine-last molar; $C I L$, condyle-incisive length; $F A$, forearm length; GLS, greatest length of skull; $M-M$, upper molar breadth; MAL, mandible length; $N$ : number of specimens; PAL, palatal length; POB, post-orbital breadth; ZIB, zygomatic breadth.

\begin{tabular}{|c|c|c|c|c|c|c|}
\hline Measure & $\begin{array}{l}\text { Present study } \\
\qquad N=4\end{array}$ & $\begin{array}{c}\text { Atlantic Forest - } \\
\text { Maringá (PR) } \\
\text { (Suckow et al. 2010) } \\
\quad N=2\end{array}$ & $\begin{array}{c}\text { Atlantic Forest - Três } \\
\text { Barras (PR) } \\
\text { (Suckow et al. 2010) } \\
N=6\end{array}$ & $\begin{array}{c}\text { Caatinga - Ararauna } \\
\text { (PB) } \\
\text { (Feijó et al. 2010) } \\
N=2\end{array}$ & $\begin{array}{l}\text { Pooled specimens of } \\
\text { Brazil and Bolivia } \\
\text { (Gregorin et al. 2016) } \\
\qquad N=12\end{array}$ & $\begin{array}{c}\text { South America } \\
(\text { Eger, 1977) }\end{array}$ \\
\hline FA & $80.3-82.9$ & $73.8-80.9$ & $78.3-81.3$ & $78.0-80.0$ & - & $78.5-80.2$ \\
\hline GLS & $31.80-32.00$ & $33.2^{\dagger}$ & - & $31.1^{\dagger}$ & $30.85-34.00$ & $32.5-33.6$ \\
\hline CIL & $31.10-31.70$ & $32.2^{\dagger}$ & - & - & $30.07-32.68$ & $31.0-32.1$ \\
\hline PAL & $12.20-12.90$ & - & - & $13.7^{\dagger}$ & $10.93-19.37$ & \\
\hline ZIB & $19.10-19.50$ & $18.9-19.6$ & $18.1-18.7$ & $17.7-18.9$ & $17.69-19.36$ & $18.4-19.0$ \\
\hline POB & $5.70-6.00$ & $5.5-5.9$ & $5.5-5.8$ & $5.4-5.7$ & $5.22-5.89$ & $5.3-5.5$ \\
\hline$B C B$ & $13.10-13.40$ & - & - & $14.6^{\dagger}$ & $12.56-15.45$ & \\
\hline$C-M$ & $12.90-13.30$ & $12.7-3.2$ & - & $12.7^{\dagger}$ & $12.50-13.44$ & \\
\hline$M-M$ & $13.10-13.50$ & $12.5-13.4$ & $12.9-13.3$ & $13.0-13.3$ & $12.54-13.40$ & \\
\hline MAL & $23.20-24.20$ & - & - & - & $23.33-25.72$ & \\
\hline$c-m$ & $14.60-14.70$ & - & - & $13.6-13.7$ & $13.61-14.56$ & $12.8-13.1$ \\
\hline
\end{tabular}

${ }^{\dagger}$ Represents the measurements of one individual.

${ }^{\ddagger}$ Number $(N)$ of evaluated bats not included since for each measure authors used different number of animals. 


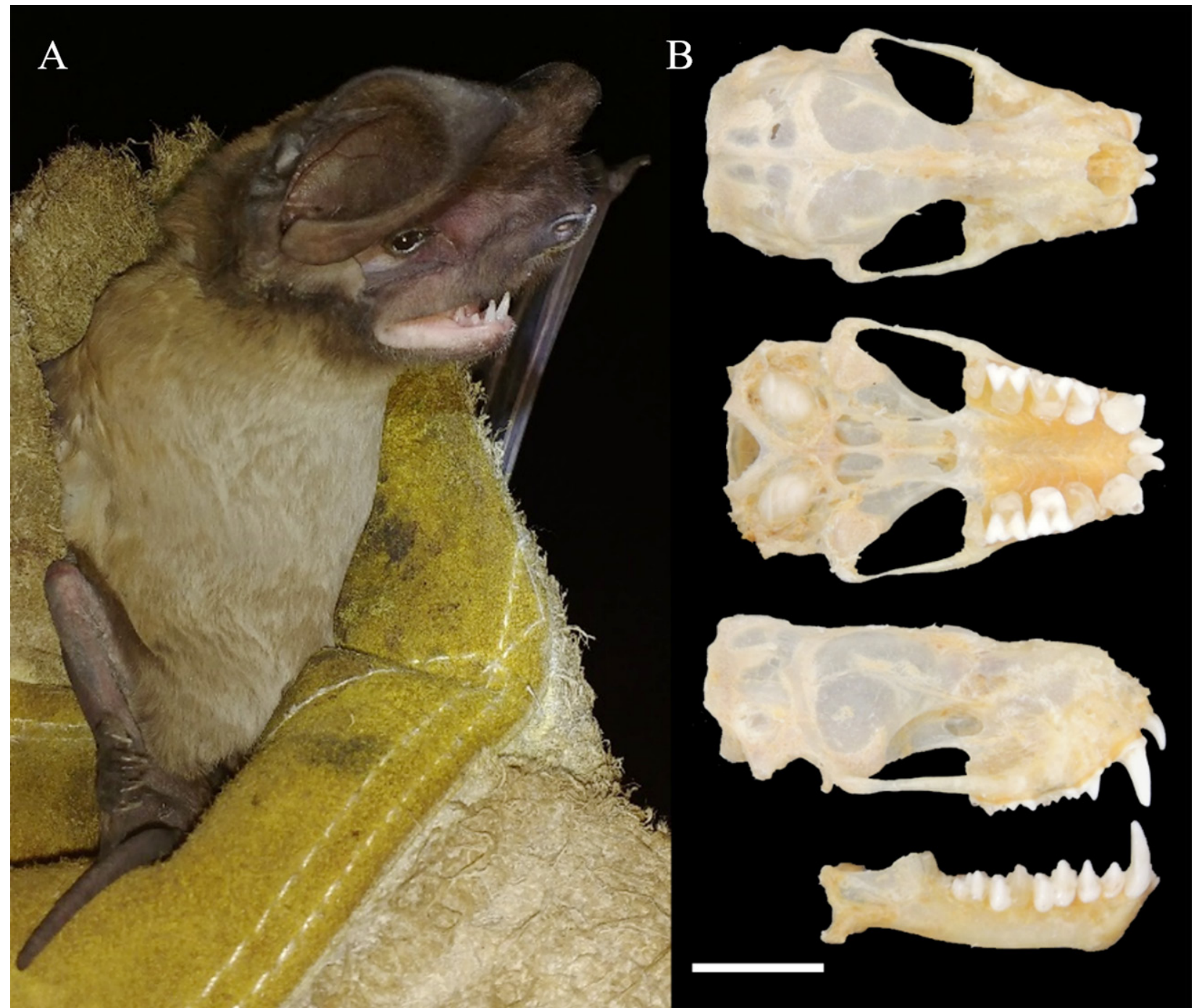

Figure 2. Eumops perotis specimen from Campo Grande, in the Cerrado of Mato Grosso do Sul, Central-West Brazil. A. Adult male (ZUFMSCHI 02498). B. Dorsal, ventral, and lateral views of the skull and mandible (views of the part of the skull ZUFMS-CHI 02498). Scale bar: $10 \mathrm{~mm}$.

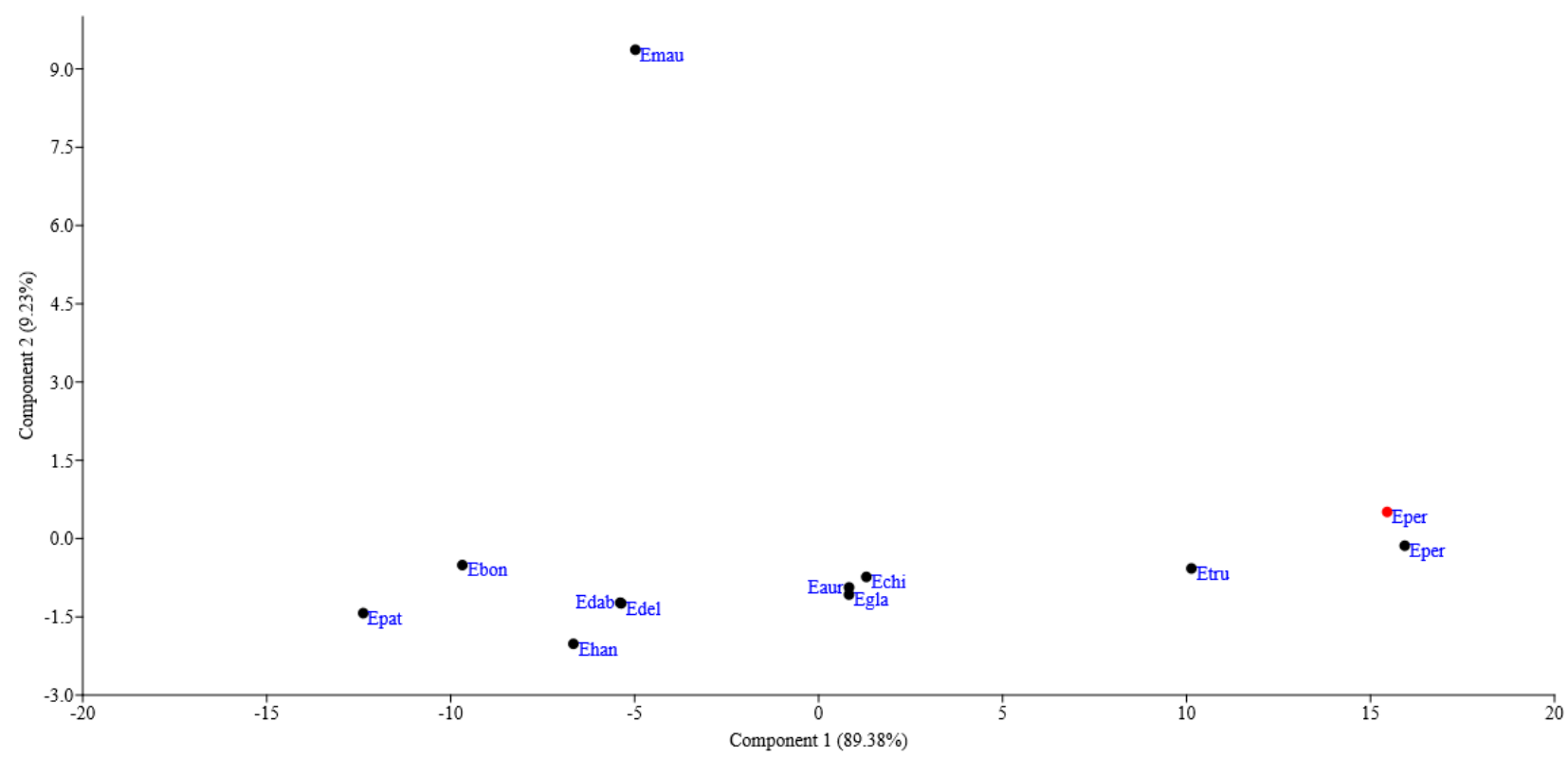

Figure 3. Scatterplot representation of the first two components obtained in the PCA of external and cranial measurement variation of species of Eumops. Red cicle: Eumops perotis (current records). Black circles: Eumops species that occur in Brazil. Eaur: Eumops auripendulus; Ebon: Eumops bonariensis; Echi: Eumops chimaera; Edab: Eumops dabbenei; Edel: Eumops delticus; Egla: Eumops glaucinus; Ehan: Eumops hansae; Emau: Eumops maurus; Epat: Eumops patagonicus; Eper: Eumops perotis; Etru: Eumops trumbulli. 
Minas Gerais (Stutz et al. 2004), São Paulo (Uieda and Chaves 2005), Distrito Federal (Pacheco et al. 2010), and Goiás (Nunes et al. 2017). Most of these records were close to the limit with the Atlantic Forest (Eger 1977; Stutz et al. 2004; Uieda and Chaves 2005). We clarify that the distribution of $E$. perotis shown in Figure 1 does not include its occurrence in the Federal District, as indicated by Pacheco et al. (2010), and Goiás, as indicated by Nunes et al. (2017), because these authors did not present the geographical coordinates of the species records. The few records of $E$. perotis from Cerrado may be the result of insufficient inventories in this biome, as studies are not well distributed in its area (Shapiro and Bordignon 2014). In addition, molossids are difficult to be captured with ground-level mist nets due to their high flights (Taylor and Tuttle 2019).

The current list of bat species from Mato Grosso do Sul (Fischer et al. 2015) reported E. perotis only in the Pantanal biome, based on one voucher specimen deposited in the Zoological Reference Collection of the Federal University of Mato Grosso do Sul (ZUFMS 0045). Therefore, our record expands the occurrence of E. perotis in the Cerrado portion of Mato Grosso do Sul, broadening its distribution in this biome, and contributing to fill gaps in the known distribution of the species.

\section{Acknowledgements}

We are thankful to the Environmental Military Police of Campo Grande for the authorization to carry out the study around the Florestinha Environmental Education Center. CAPES for the scholarship grant of JMT (88887.149141/2017-00) and FMS (88887.369261/201900). We thank the students of the INSANA HUNA group for their assistance in the field activities and Breno Emanuel Frihling for his help with image editing. This study was financed by Universidade Católica Dom Bosco (UCDB) and Fundação de Apoio ao Desenvolvimento do Ensino, Ciência e Tecnologia do Estado de Mato Grosso do Sul (FUNDECT), Edital: Chamada FUNDECT no. 10/2015 UNIVERSAL-MS, and in part by Universidade Federal de Mato Grosso do Sul-UFMS/MEC-Brazil and Coordenação de Aperfeiçoamento de Pessoal de Nível Superior-Brasil (CAPES) Finance Code 001.

\section{Authors' Contributions}

JMT and PI conducted the survey. JMT identified the specimens. JMT, GEOP, MOB, FMS, and CEO wrote and revised the text.

\section{References}

Anderson S (1972) Mammals of Chihuahua: taxonomy and distribution. Bulletin of the American Museum of Natural History 148: 149-410.

Barquez RM, Díaz MM (2001) Bats of the Argentine Yungas: a systematic and distributional analysis. Acta Zoologica Mexicana 82: $29-81$.
Bernardi IP, Miranda JMD, Passos FC (2009) Status taxonômico e distribucional do complexo Eumops bonariensis (Chiroptera: Molossidae) no sul do Brasil. Zoologia 26 (1): 183-190. https:// doi.org/10.1590/S1984-46702009000100025

Best TL, Kiser WM, Freeman PW (1996) Eumops perotis. Mammalian Species 534: 1-8. https://doi.org/10.2307/3504077

Breviglieri CPB, Esbérard CEL (2018) Use of roof as roost of Eumops perotis (Molossidae: Chiroptera) in southeast Brazil. Iheringia, Série Zoologia 108: e2018033. https://doi.org/10.1590/1678$4766 \mathrm{e} 2018033$

Castilho JG, Canello FM, Scheffer KC, Achkar SM, Carrieri ML, Kotait I (2008) Antigenic and genetic characterization of the first rabies virus isolated from the bat Eumops perotis in Brazil. Revista do Instituto de Medicina Tropical de São Paulo 50 (2): 95-99. https://doi.org/10.1590/S0036-46652008000200006

Czaplewski NJ, Cartelle C (1998) Pleistocene bats from cave deposits in Bahia, Brazil. Journal of Mammalogy 79 (3): 784-803. https:// doi.org/10.2307/1383089

Eger JL (1977) Systematics of the genus Eumops (Chiroptera: Molossidae). Life Sciences Contributions, Royal Ontario Museum 110: $1-69$.

Eger JL (2008) Family Molossidae. In: Gardner AL (Ed.) Mammals of South America, volume 1: marsupials, xenarthrans, shrews, and bats. University of Chicago Press, Chicago, 399-440.

Escarlate-Tavares F, Pessôa LM (2005) Bats (Chiroptera, Mammalia) in Barn Owl (Tyto alba) pellets in northern Pantanal, Mato Grosso, Brazil. Mastozoologia Neotropical 12 (1): 61-67.

Falcão FC, Rebêlo VF, Talamoni SA (2003) Structure of a bat assemblage (Mammalia, Chiroptera) in Serra do Caraça Reserve, South-east Brazil. Revista Brasileira de Zoologia 20 (2): 347-350. https://doi.org/10.1590/S0101-81752003000200027

Feijó JA, Araujo P, Fracasso MPA, dos Santos KRP (2010) New records of three bat species for the Caatinga of the state of Paraíba, northeastern Brazil. Chiroptera Neotropical 16 (2): 723-727.

Fischer E, Santos CF, Carvalho LFAC, Camargo G, Cunha NL, Silveira M, Bordignon MO, Silva CL (2015) Bat fauna of Mato Grosso do Sul, southwestern Brazil. Biota Neotropica 15 (2): e20140066. https://doi.org/10.1590/1676-06032015006614

Gómez-Hernández C, Bento EC, Rezende-Oliveira K, Nascentes GAN, Barbosa CG, Batista LR, Tiburcio MGS, Pedrosa AL, Lages-Silva E, Ramírez JD, Ramirez LE (2017) Leishmania infection in bats from a non-endemic region of Leishmaniasis in Brazil. Parasitology 144 (14): 1980-1986. https://doi.org/10.1017/S00 31182017001500

Gregorin R, Taddei VA (2002) Chave artificial para a identificação de molossídeos brasileiros (Mammalia, Chiroptera). Mastozoología Neotropical 9 (1): 13-32.

Gregorin R, Moras LM, Acosta LH, Vasconcellos KL, Pomas JL, Santos FR, Paca RC (2016) A new species of Eumops (Chiroptera: Molossidae) from southeastern Brazil and Bolivia. Mammalian Biology 81 (3): 235-246. https://oi.org/10.1016/j.mambio.2016.01.002

Hammer O, Harper DAT, Rian PD (2001) Past: palaeontological statistics software package for education and data analysis. Paleontologia Electronica 4 (1): 1-9.

Johnson RA, Wichern DW (1992) Applied multivariate statistical analysis. Prentice-Hall International, Englewood Cliffs, New Jersey, 642 pp.

López-Baucells A, Rocha R, Tavares VC, Moras LM, Silva SE, Bobrowiec PED, Meyer CFJ (2017) Molecular, morphological and acoustic identification of Eumops maurus and Eumops hansae (Chiroptera: Molossidae) with new reports from Central Amazonia. Tropical Zoology 31: 1-20. https://doi.org/10.1080/03946975. 2017.1382284

Marchesin SRC, Beguelini MR, Faria KC, Moreira PRL, MorielleVersute E (2008) Assessing genetic variability in bat species of Emballonuridae, Phyllostomidae, Vespertilionidae and Molossidae families (Chiroptera) by RFLP-PCR. Genetics and Molecular 
Research 7 (4): 1164-1178

Moratelli R, Dias D, Bonvicino CR (2010) Estrutura e análise zoogeográfica de uma taxocenose de morcegos no norte do Estado do Amazonas, Brasil. Chiroptera Neotropical 16: 661-671.

Nogueira MR, Lima IP, Garbino GST, Moratelli R, Tavares VC, Gregorin R, Peracchi AL (2018) Updated checklist of Brazilian bats: version 2018. Comitê da Lista de Morcegos do Brasil-CLMB. Sociedade Brasileira para o Estudo de Quirópteros (Sbeq) https://www.sbeq.net/lista-de-especies. Accessed on: 2019-6-10.

Nunes H, Rocha FL, Cordeiro-Estrela P (2017) Bats in urban areas of Brazil: roosts, food resources and parasites in disturbed environments. Urban Ecosystems 20 (4): 953-969. https://doi.org/10. 1007/s11252-016-0632-3

Pacheco SM, Freitas TRO (2003) Quirópteros. In: Fontana CS, Bencke GA, Reis RE (Eds) Livro vermelho da fauna ameaçada de extinção no Rio Grande do Sul. EDIPUCRS, Porto Alegre, 483497.

Pacheco SM, Sodré M, Gama AR, Bredt A, Cavallini EM, Marques SRV, Guimarães MM, Bianconi G (2010) Morcegos urbanos: status do conhecimento e plano de ação para a conservação no Brasil. Chiroptera Neotropical 16 (1): 629-647.

Piccinini RS (1974) Lista provisória dos quirópteros da coleção do Museu Paraense Emílio Goeldi (Chiroptera). Boletim do Museu Paraense Emilio Goeldi, Zoologia 7: 1-32.

Reis NR, Peracchi AL, Batista CB, Lima IP, Pereira AD (2017) História natural dos morcegos brasileiros: chave de identificação de es- pécies. Technical Books Livraria, Rio de Janeiro, 416 pp.

Sartore ER, Tavares VC, Moras LM (2017) Família Molossidae. In: Reis NR, Peracchi AL, Batista CB, Lima IP, Pereira AD (Eds) História natural dos morcegos brasileiros: chave de identificação de espécies. Technical Books Editora, Rio de Janeiro, 274-318.

Shapiro JT, Bordignon MO (2014) Bat (Chiroptera) assemblages in three Cerrado fragments of Mato Grosso do Sul, southwestern Brazil. Check List 10 (6): 1380-1386. https://doi. org $/ 10.15560 / 10.6 .1380$

Sodré MM, Rosa AR, Gregorin R, Guimarães MM (2008) Range extension for Thomas' Mastiff bat Eumops maurus (Chiroptera: Molossidae) in northern, central and southeastern Brazil. Revista Brasileira de Zoologia 25 (2): 379-382. http://doi.org/10.1590/ S0101-81752008000200027

Stutz WH, Albuquerque MC, Uieda W, Macedo EM, França CB (2004) Updated list of Uberlândia bats. Chiroptera Neotropical 10 (1-2): 188-190.

Suckow UMS, Bianconi GV, Parolin LC, Lima IP (2010) First occurrences of the greater bonneted Eumops perotis (Molossidae) in the state of Paraná and synthesis of the known records for Brazil. Biota Neotropica 10 (3): 453-456. http://doi.org/10.1590/S167606032010000300039

Taylor M, Tuttle M (2019) Bats: an illustrated guide to all species. Smithsonian Books, Washington, DC, 400 pp.

Uieda W, Chaves ME (2005) Bats from Botucatu Region, state of São Paulo, southeastern Brazil. Chiroptera Neotropical 11 (1-2): 224-22.

\section{Appendix}

Table A1. Locality records of Eumops perotis in Brazil. The asterisk indicates the new record from Campo Grande (this study), in the Cerrado of Mato Grosso do Sul state, Central-West Brazil.

\begin{tabular}{|c|c|c|c|c|c|}
\hline Record no. & Municipality or locality & State & Latitude & Longitude & References \\
\hline 1 & Paranã do Manhana & $A M$ & $01^{\circ} 50^{\prime} 00.00^{\prime \prime} \mathrm{S}$ & $067^{\circ} 00^{\prime} 00.00^{\prime \prime} \mathrm{W}$ & Suckow et al. 2010 \\
\hline 2 & Santa Isabel do Rio Negro & AM & $00^{\circ} 24^{\prime} 51.04^{\prime \prime} \mathrm{S}$ & $065^{\circ} 00^{\prime} 52.96^{\prime \prime} \mathrm{W}$ & Moratelli et al. 2010 \\
\hline 3 & Barcelos & AM & $00^{\circ} 58^{\prime} 26.35^{\prime \prime S}$ & $062^{\circ} 55^{\prime} 32.10^{\prime \prime} \mathrm{W}$ & Moratelli et al. 2010 \\
\hline 4 & Rodovia AM-10 (Manaus - Itacoatiara) & AM & $02^{\circ} 57^{\prime} 00.00^{\prime \prime S}$ & $059^{\circ} 15^{\prime} 00.00^{\prime \prime} \mathrm{W}$ & Piccinini 1974 \\
\hline 5 & Belém & PA & $01^{\circ} 28^{\prime} 00.00^{\prime \prime S}$ & $048^{\circ} 26^{\prime} 00.00^{\prime \prime} \mathrm{W}$ & Piccinini 1974 \\
\hline 6 & Barro do Corda & MA & $05^{\circ} 30^{\prime} 00.00^{\prime \prime} \mathrm{S}$ & $045^{\circ} 05^{\prime} 00.00^{\prime \prime} \mathrm{W}$ & Eger 1977 \\
\hline 7 & Araruna & PB & $06^{\circ} 27^{\prime} 32.39^{\prime \prime} S$ & $035^{\circ} 40^{\prime} 44.67^{\prime \prime} \mathrm{W}$ & Feijó et al. 2010 \\
\hline 8 & Sete Lagoas & $\mathrm{PI}$ & $08^{\circ} 27^{\prime} 00.00^{\prime \prime} S$ & $041^{\circ} 42^{\prime} 00.00^{\prime \prime} \mathrm{W}$ & Eger 1977 \\
\hline 9 & Gruta dos Brejões & BA & $11^{\circ} 00^{\prime} 24.63^{\prime \prime S}$ & $041^{\circ} 26^{\prime} 09.68^{\prime \prime} \mathrm{W}$ & Czaplewski and Cartelle 1998 \\
\hline 10 & Barão de Melgaço & MT & $16^{\circ} 17^{\prime} 02.31^{\prime \prime S}$ & $056^{\circ} 00^{\prime} 08.03^{\prime \prime} \mathrm{W}$ & Escarlate-Tavares and Pêssoa 2005 \\
\hline 11 & Corumbá & MS & $19^{\circ} 23^{\prime} 60.00^{\prime \prime} \mathrm{S}$ & $057^{\circ} 21^{\prime} 00.00^{\prime \prime} \mathrm{W}$ & Fischer et al. 2015 \\
\hline 12 & Uberlândia & MG & $18^{\circ} 55^{\prime} 00.00^{\prime \prime} \mathrm{S}$ & $048^{\circ} 16^{\prime} 60.00^{\prime \prime} \mathrm{W}$ & Stutz et al. 2004 \\
\hline 13 & Água Comprida & MG & $20^{\circ} 03^{\prime} 28.94^{\prime \prime} \mathrm{S}$ & $048^{\circ} 06^{\prime} 26.38^{\prime \prime} \mathrm{W}$ & Gómez-Hernández et al. 2017 \\
\hline 14 & Lagoa Santa & MG & $19^{\circ} 38^{\prime} 60.00^{\prime \prime} \mathrm{S}$ & $043^{\circ} 44^{\prime} 00.00^{\prime \prime} \mathrm{W}$ & Eger 1977 \\
\hline 15 & Serra da Caraça & MG & $20^{\circ} 04^{\prime} 60.00^{\prime \prime} \mathrm{S}$ & $043^{\circ} 29^{\prime} 00.00^{\prime \prime} \mathrm{W}$ & Falcão et al. 2003 \\
\hline 16 & Mariana & $M G$ & $20^{\circ} 22^{\prime} 60.00^{\prime \prime} \mathrm{S}$ & $043^{\circ} 24^{\prime} 60.00^{\prime \prime} \mathrm{W}$ & Eger 1977 \\
\hline 17 & Mirassol & SP & $20^{\circ} 49^{\prime} 02.56^{\prime \prime S}$ & $049^{\circ} 30^{\prime} 17.66^{\prime \prime} \mathrm{W}$ & Marchesin et al. 2008 \\
\hline 18 & São José do Rio Preto & SP & $20^{\circ} 48^{\prime} 45.76^{\prime \prime} \mathrm{S}$ & $049^{\circ} 22^{\prime} 35.48^{\prime \prime} \mathrm{W}$ & Marchesin et al. 2008 \\
\hline 19 & Bady Bassitt & SP & $20^{\circ} 54^{\prime} 58.96^{\prime \prime S}$ & $049^{\circ} 26^{\prime} 55.83^{\prime \prime} \mathrm{W}$ & Marchesin et al. 2008 \\
\hline 20 & Pindorama & SP & $21^{\circ} 11^{\prime} 30.76^{\prime \prime} S$ & $048^{\circ} 53^{\prime} 31.92^{\prime \prime} \mathrm{W}$ & Breviglieri and Esbérard 2018 \\
\hline 21 & Ribeirão Preto & SP & $21^{\circ} 10^{\prime} 13.44^{\prime \prime} \mathrm{S}$ & $047^{\circ} 48^{\prime} 37.17^{\prime \prime} \mathrm{W}$ & Castilho et al. 2008 \\
\hline 22 & Botucatu & $S P$ & $22^{\circ} 52^{\prime} 56.08^{\prime \prime S}$ & $048^{\circ} 26^{\prime} 51.60^{\prime \prime} \mathrm{W}$ & Uieda and Chaves 2005 \\
\hline 23 & São Paulo & SP & $23^{\circ} 27^{\prime} 60.00^{\prime \prime S}$ & $046^{\circ} 37^{\prime} 60.00^{\prime \prime} \mathrm{W}$ & Sodré et al. 2008 \\
\hline 24 & Campos dos Goytacazes & RJ & $21^{\circ} 48^{\prime} 60.00^{\prime \prime S}$ & $041^{\circ} 15^{\prime} 60.00^{\prime \prime} \mathrm{W}$ & Eger 1977 \\
\hline 25 & Itaguaí & RJ & $22^{\circ} 51^{\prime} 00.00^{\prime \prime} \mathrm{S}$ & $043^{\circ} 46^{\prime} 60.00^{\prime \prime} \mathrm{W}$ & Eger 1977 \\
\hline 26 & Rio de Janeiro & RJ & $22^{\circ} 52^{\prime} 60.00^{\prime \prime S}$ & $043^{\circ} 16^{\prime} 60.00^{\prime \prime} \mathrm{W}$ & Eger 1977 \\
\hline 27 & Londrina & $P R$ & $23^{\circ} 18^{\prime} 15.09^{\prime \prime S}$ & $051^{\circ} 10^{\prime} 09.86^{\prime \prime} \mathrm{W}$ & Suckow et al. 2010 \\
\hline 28 & Maringá & $P R$ & $23^{\circ} 25^{\prime} 15.60^{\prime \prime S}$ & $051^{\circ} 55^{\prime} 59.00^{\prime \prime} \mathrm{W}$ & Suckow et al. 2010 \\
\hline 29 & Três Barras do Paraná & $P R$ & $25^{\circ} 25^{\prime} 18.43^{\prime \prime} \mathrm{S}$ & $053^{\circ} 11^{\prime} 03.51^{\prime \prime} \mathrm{W}$ & Suckow et al. 2010 \\
\hline 30 & Victor Graeff & RS & $28^{\circ} 33^{\prime} 37.78^{\prime \prime} \mathrm{S}$ & $052^{\circ} 44^{\prime} 58.60^{\prime \prime} \mathrm{W}$ & Pacheco and Freitas 2003 \\
\hline * & Campo Grande & MS & $20^{\circ} 24^{\prime} 09.38^{\prime \prime S}$ & $054^{\circ} 33^{\prime} 53.78^{\prime \prime} \mathrm{W}$ & New record \\
\hline
\end{tabular}

